\title{
A Discussion of the Liability Principles of School Incidents
}

\author{
Mei Liu ${ }^{1, a}$ \\ ${ }^{1}$ School of Teacher Education, Kunming University, \\ Kunming, China \\ aLiumei_2004@tom.com
}

\author{
$\mathrm{Ke} \mathrm{Su}{ }^{2, b}$ \\ ${ }^{2}$ School of Applied English Studies, Shandong University \\ of Finance and Economics, Jinan, China \\ bsuker1979@163.com
}

\begin{abstract}
A common opinion of the modern society believes that schools should ensure that absolutely neither incidents nor injuries would happen to students who are minors and schools or teachers should be liable in case of any incidents. In order to address correct this misunderstanding, this paper provides a brief prudential analysis on the liability principles of school incidents.
\end{abstract}

Keywords: school incident, infringement, liability principle

\section{INTRODUCTION}

Although existing studies generally use the concept of "school incident", there has yet to be a unified legal concept for such, and various interpretations exist in terms of connotations and extensions. Different experts and academics also have differences in terms of understanding when applying this concept, with some using its time concept and others using its spatial concept; some believe that school incidents are personal injury incidents that exclude damage to properties, while others feel that property damage should be included; some are of the view that school incidents are the students' personal injuries while others believe the personal injuries of teachers and other personnel should also be included; there are also people who believe that the students referred to in school incidents comprise only minors, which is an area that is worth further discussion. This study defines school incidents as personal injury incidents that occur during the time students are in school. The "time in school" is a spatial concept, which refers to the time between students' registration and enrollment in schools and their graduation.

\section{Types of school incidents}

2.1 School incidents caused by inadequate school facilities or potential safety hazards

For example, on September 26, 2014, at about 2.30p.m, when a stampede incident occurred at the Ming Tong Primary School in Kunming's Panlong District. This incident led to 6 student fatalities and 26 injuries, of which, 2 were severe injuries. Investigation revealed that the incident was caused by a fallen mattress that was lying flat across the first floor corridor, causing the path to be obstructed. Students who walked pass the mattress first tripped and fell, while students who followed were unaware of the situation and continued to press forward, causing overlapping and squeezing of students that eventually led to severe student injuries and fatalities. This was a typical example of a school incident caused by inadequate school facilities or potential safety hazards. The main cause of this type of incident is due to the lack of responsibility and accountability and safety awareness of school management and relevant persons in charge.

\subsection{School incidents as a result of infringement by schools or teachers}

Corporal punishments or disguised corporal punishments are typical infringements of student rights by schools and teachers. With improved legal awareness of teachers and growing social and media attention, such violent physical infringements have become very rare in the modern society, however, the phenomenon of other infringements of student rights have yet to be entirely overturned. In daily learning activities, we still observe some specific manifestations of such infringements, as shown in the following two areas.

(i) Infringement on student freedom. Teachers often unconsciously infringe on student freedom during learning activities, such as prolonging class or school hours without valid reasons and depriving students of time for extra curriculum activities, this is particularly common for the so called responsible teachers, who often drag classes and take up recess time or conduct remedial 
classes for no valid reasons. Further, punishments such as standing at attention, cleaning, copying homework, running and "half squats" are all examples of more "civilized" measures of disciplinary actions.

(ii) Infringement on student dignity. Irony, sarcasm, insults, abusive remarks and discriminatory nicknames are all examples of methods that academics refer to as "verbal violence". Although students are minors, they do have their personal dignity. Further, as their psychological vulnerability and sensitivity are unimaginable for adults, the consequences of such "verbal violence" are also hard to imagine or predict. For example, a media report revealed that a student committed suicide simply because her teacher said she was stupid and would not fit to even become a hostess. Such painful lessons should keep us alert.

Article 15 of "The Law of the People's Republic of China on the Protection of Minors" stipulates that "The teaching and administrative staffs in schools or kindergartens may not commit any activity infringing upon the personal dignity of minor students or children, nor physical punishment, disguised physical punishment nor any other such behaviors."

\subsection{School incidents caused by third parties}

School incidents caused by third parties can primarily be classified into the following:

(i) Student injury incidents caused by the faults of venue provided, equipment, transportation, food and operators of other consumables and services, or event organizers other than the school, when schools arrange for student to participate in activities.

(ii) Student injury occurred as a result of the personal conduct of school teachers or other staff that is unrelated to their duties, or due to intentional criminal behavior of students, teachers or other individuals.

(iii) Student injury incidents caused by the fault of third parties.

\subsection{School incidents caused by the student}

Student injury incidents caused by students' violation of school rules, or as a result of failed resuscitation attempts due to special individual physical conditions, or student behaviors such as self-mutilation and suicide, etc.

\section{The liability principles of school incidents}

School liability refers to the civil liability that arises out of student injury incidents caused by schools or teachers (including action and inaction). As a result of the generalized understanding of school liability by legal research and judicial practices, once student injury incidents occur, they are often deemed to be caused by inadequacy in the management of schools, and hence schools should bear certain damage liabilities. Lack of clarity in determining the liabilities of school incidents will have severe negative impacts on the enthusiasm of schools and teachers, education reform and development, safeguarding the spirit of the law and nation-building based on the rule of law. Therefore, the scientific definition of school liability and the scope of compensation in school incidents, i.e., the scientific definition of the school's fault, has become a core issue in the appropriate resolution of such legal disputes.

\subsection{Application of the principle of fault liability in school incident liability}

The infringements by schools or teachers are the prerequisite for fault, where schools or teachers infringe upon the legal rights of students. First, the legal rights of others must be infringed upon by the action or inaction of the offender. Lack of either action or damage does not constitute infringement. Second, the objects of the infringement must be the student's personal rights, as what is violated by infringement is not common right, but absolute right, that is, the right to take some action or to refrain from acting at the sole discretion of the person having the right, including property rights and personal rights. Lastly, it must be action caused by the faults of the school or teacher, as faults are a necessary condition for infringement. In terms of the concept of fault, it includes the inappropriateness and blameworthiness of the offender's subjective state, and also includes objective unlawful acts. Infringements can be determined if the actions of schools and teachers possess the above unlawful characteristics.

\subsection{Application of the principle of limited liability in school incident liability}

Within the scope of our understanding, no country states that schools must assume unlimited risks for student injuries. The principle of limited liability is the common view adopted by countries in establishing legislation on school incidents. In the United States, the legal liability of schools or teachers as a result of fault is determined based on the provisions for negligence in the common law, this type of civil infringement laws are generally created by judges. During the trial of such cases, the court can only require the school to bear liability when it is able to prove that the school has not entirely exercised its "cautious obligations" and caused damages to occur, otherwise, the school can disclaim such liability. At the same time, having the school bearing the entire liability can significantly restrict normal activities in school. As it is unfair for schools to undertake unlimited liability, schools can therefore only take on limited liability. Specifically, schools only need to be responsible for their own faults, and not unlimited liabilities. Article 40 of "The Infringement Law of the People's Republic of China" stipulates that "Where during the studying and living period in a kindergarten, school or other educational institution, a person without or with limited 
capacity for civil is caused physical injury by a person outside of the kindergarten, school or other educational institution, the infringer shall bear the liability for infringement; where the kindergarten, school or other educational institution have not performed their duty of management, they shall bear additional corresponding liability." Judges in the United States also support the view that "a school is not an insurer of a student's absolute safety, and it has no absolute liability for all the injuries that happen to a student"

\subsection{Application of the principle of presumption of fault in school incident liability}

The principle of presumption of fault refers to the liability principle of presuming the offender's faults based on the damage itself in special infringement behaviors, and subsequently determining the offender's compensation liability. In China's tort law liability principle system, fault liability principle is applicable to common infringement behaviors while the presumption of fault principle is applicable to all types of special infringement behaviors. School infringement incidents are often triggered by common civil infringement behaviors, and thus generally adopt the presumption of fault principle, however, this does not rule out the possibility of schools having special infringement behaviors. For example, Article 126 of the "General Principles of the Civil Law of the People's Republic of China" stipulates that "If a building or any other installation or an object placed or hung on a structure collapses, detaches or drops down and causes damage to others, its owner or manager shall bear civil liability, unless he can prove himself not at fault." What this article establishes is a type of special infringement behavior, where the presumption of fault principle is applicable. In addition, for victims in kindergartens or those below 10 years of age, it is difficult to prove the causal relation between violations and consequences due to the constraints posted by the age of the victims, therefore the principle of presumption of fault is often used in such cases as well. In other words, in the event kindergartens and schools fail to exercise their duty of care and subsequently lead to the injury of people with no civil capacity, they are liable for civil liabilities. Based on our knowledge of the suggested draft of the China Civil Code, the draft prepared by the China Academy of Social Sciences' task force says that "For injuries caused to others by people with no or limited civil capacity, and study or live in nurseries, kindergartens and schools, the nurseries, kindergartens and schools shall bear civil liability, unless they can prove themselves not at fault; in cases where nofault is proven, then the guardians shall bear civil liability. Schools that violate their safety protection obligations and cause student injuries due to inadequate school facilities or management shall bear civil liability." [2]

\subsection{School incident liability does not apply to the principle of no-fault}

Under many circumstances, what no-fault principle establishes is not truly no-fault, as people can presume the perpetrator's intentional or unconscious negligence from the damage itself. Therefore, the main characteristics of the no-fault principle is: it does not see the perpetrator's subjective fault as the element of infringement, and whether or not the offender is subjectively at fault, he needs to bear infringement liability. The intention is to emphasize on certain special areas, such as high risk operations, environmental protection and product responsibility. The fault of offenders in this type of incidents are difficult to determine, and hence can only be presumed that the offender lacks adequate care and diligence. The realization of this proposition is: the law stipulates nofault provisions in areas such as high risk operations, where the victims only needs to prove that the damage conforms to the legal provisions for infringement, and needs not prove the subjective fault of the offender to support his proposition. In this case, only the causal relation is the fundamental condition for determining the liability of the offender, as long as there is a causal relationship between the actions of the offender and the resultant damage, then the offender needs to bear infringement liability. The offender must prove the existence of the statutory exemptions as his exemption conditions. Based on the above characteristics, the principle of no-fault liability is only applicable to certain special civil infringement behaviors, and its application scope should be specifically determined by law.

Given the legal spirit supported by the no-fault liability principle, can this principle then be applied in schools? The answer is negative. First, in terms of the nature of school incidents, it is characterized as a relatively conventional and typical civil infringement behavior and its construct is also relatively simple, whereby it is relatively easy to prove the causal relations, and does not possess the complexity in construct and proof seen in the above new type of infringement behaviors. There is also no problem determining the causal relation between the negligence of schools or teachers and the damages caused, as the difficulty for proof will not be increased, and it is therefore appropriate to establish the fault liability principle. Second, the civil laws in China establish that the application scope of nofault liability principle is very limited, such that unintentional damages can be reasonably shared by the country and the society, thereby protecting the welfare of the victims. For people engaged in high risk operations and activities, product manufacturing and sales, as well as livestock keeping and management, establishing the nofault liability principle is beneficial in ensuring that the 
perpetrators would place great emphasis on their work, enhance work quality and ensure the safety of the surrounding population and environment as far as possible. The educational activities carried out by schools are obviously not characterized as high risk, and hence there is no valid reason for establishing no-fault liability. Further, the establishment of no-fault liability is intended at promoting adequate care and diligence among perpetrators, so as to avoid causing damage to others.

\section{CONCLUSIONS}

Based on the above, school incidents that lead to the physical injury of students can constitute infringement behavior, administrative violation or criminal offense, and must be subject to civil, administrative or criminal legal liabilities. The liabilities borne by schools or teachers can only be attributed by fault liabilities that arise out of their tort behaviors. continually improve on technical safety measurements,

\section{Acknowledgments}

This paper is the result of the 2012 Scientific Research Fund Program "A Jurisprudence Study of School Incidents" under the Yunnan Provincial Department of Education. Program serial number: 2013 C084.

\section{References}

[1]. Wang Sheng Zhou: Jurisprudence [M], Beijing: The People's Court Press, 2002.

[2]. Shi Quan Cao: A Study on the Guardianship System of Minors [M], Beijing: China University of Political Science and Law Press, 2004. 